\title{
Microbacterium radiodurans sp. nov., a UV radiation-resistant bacterium isolated from soil
}

Correspondence
Hong-hui Zhu
zhuhonghui66@163.net

Orla-Jensen (1919) established the genus Microbacterium, class Actinobacteria, with only four species. At the time of writing, the genus includes 60 species (http://www. bacterio.cict.fr $/ \mathrm{m} / \mathrm{microbacterium}$.html). Some species of the genera Brevibacterium (Collins et al., 1983; Schumann et al., 1999) and Flavobacterium (Imai et al., 1984; Takeuchi \& Hatano, 1998a) have been reclassified as species of the genus Microbacterium and a comparative sequence analysis of the 16S rRNA gene led to the unification of the genera Microbacterium and Aureobacterium (Takeuchi \& Hatano, 1998b; Behrendt et al., 2001). Members of the genus Microbacterium have mainly been isolated from environmental habitats. Here, we describe the phenotypic and genotypic properties of a strain belonging to the genus Microbacterium that was isolated from the upper sand layers of the Gobi desert,

†These authors contributed equally to this work.

The GenBank/EMBL/DDBJ accession number for the 16S rRNA gene sequence of strain GIMN $1.002^{\top}$ is G0329713.

A figure presenting survival curves after exposure to UV light for strain GIMN $1.002^{\top}$ and its two closest phylogenetic neighbours is available as supplementary material with the online version of this paper.
Xinjiang, China, where bacteria are exposed to prolonged desiccation and cycles of high and low temperatures.

Strain GIMN $1.002^{\mathrm{T}}$ was isolated on nutrient agar (NA; Difco) after 2-4 days at $30{ }^{\circ} \mathrm{C}$. The Gram reaction was performed by the non-staining method, as described by Buck (1982). Cells for the observation of cell morphology and motility were prepared on NA at $30{ }^{\circ} \mathrm{C}$ for 2 days. Cell morphology was observed by light microscopy (Leica DM RAR) and scanning electron microscopy (Hitachi). Motility was assessed using the hanging-drop method (Skerman, 1967). Catalase activity was determined by assessing bubble production with $3 \%(\mathrm{v} / \mathrm{v}) \mathrm{H}_{2} \mathrm{O}_{2}$ and oxidase activity was determined using $1 \%(\mathrm{w} / \mathrm{v})$ tetramethyl-p-phenylenediamine. Growth at 4, 18, 25, 30, 37 and $42{ }^{\circ} \mathrm{C}$ and pH $5.0-10.0$ (in increments of $0.5 \mathrm{pH}$ units) was assessed in nutrient broth (NB; Difco) after 5 days. For the $\mathrm{pH}$ experiments, the following buffering systems were used $(50 \mathrm{mM})$ : acetate buffer ( $\mathrm{pH} 5.0-5.5)$, phosphate buffer ( $\mathrm{pH}$ 6.0-8.0) and Tris buffer ( $\mathrm{pH} 8.5-10.0)$. Salt tolerance was tested in NB supplemented with $1-10 \%$ (w/v) $\mathrm{NaCl}$ at $28{ }^{\circ} \mathrm{C}$ after 5 days. Anaerobic growth was tested at $28{ }^{\circ} \mathrm{C}$ for 7 days in 10 -ml rubber-sealed 
screw-capped tubes containing $9 \mathrm{ml} \mathrm{NB}$ that was covered with liquid paraffin. Hydrogen sulfide production and gelatin hydrolysis were determined by the general characterization methods described by Smibert \& Krieg (1981) and Sneath et al. (1986), using gelatin agar (Difco) for the gelatin hydrolysis test.

Preparation of cell walls and determination of the cell-wall diamino acids by TLC followed the procedures described by Bousfield et al. (1985). The peptidoglycan acyl type was determined according to Uchida \& Seino (1997). Polar lipids were extracted according to Minnikin et al. (1984) and were identified by two-dimensional TLC followed by spraying with appropriate detection reagents (Minnikin et al., 1984; Komagata \& Suzuki, 1987).

The utilization of substrates as sole carbon sources and the metabolic profile of strain GIMN $1.002^{\mathrm{T}}$ were examined using the GP2 MicroPlate system (Biolog), which includes an array of 96 wells to test the oxidation of 95 carbon sources. Sample preparation and analysis were performed, according to the directions of the manufacturer, in triplicate. Results were obtained after 4 and $24 \mathrm{~h}$ using a Microstation (Biolog) and the data were analysed using MICROLOG version 3 (Biolog). Of the 95 carbon sources tested, 23 could be oxidized by strain GIMN $1.002^{\mathrm{T}}: \beta$ cyclodextrin, cellobiose, gentiobiose, $\alpha$-D-glucose, inositol, maltose, maltotriose, D-mannitol, D-mannose, 3-methyl Dglucose, $\alpha$-ketoglutaric acid, succinic acid monomethyl ester, pyruvic acid methyl ester, glycyl L-glutamic acid, uridine, uridine $5^{\prime}$-monophosphate, D-xylose, salicin, Dsorbitol, D-fructose, putrescine, trehalose and $\alpha$-D-glucose 1-phosphate. Oxidation of 43 carbon sources varied between the three replicates: inulin, mannan, $N$-acetyl-Dglucosamine, $N$-acetyl- $\beta$-D-mannosamine, amygdalin, Darabitol, arbutin, L-fucose, D-gluconic acid, lactose, melezitose, melibiose, methyl $\alpha$-D-galactoside, methyl $\beta$-Dgalactoside, methyl $\beta$-D-glucoside, methyl $\alpha$-D-mannoside, palatinose, D-psicose, stachyose, turanose, lactulose, Dribose, $\alpha$-, $\beta$ - and $\gamma$-hydroxybutyric acids, $p$-hydroxyphenylacetic acid, $\alpha$-ketovaleric acid, pyruvic acid, succinamic acid, succinic acid, D-alanine, L-alanyl glycine, L-asparagine, putrescine, 2,3-butanediol, glycerol, inosine, thymidine, adenosine 5'-monophosphate, thymidine 5'-monophosphate, D-fructose 6-phosphate, D-glucose 6-phosphate and DL- $\alpha$-glycerol phosphate. The remaining 29 carbon sources tested were not oxidized by strain GIMN $1.002^{\mathrm{T}}$.

Genomic DNA from strain GIMN $1.002^{\mathrm{T}}$ was extracted and purified as described by Moore \& Dowhan (1995) and degraded enzymically into nucleosides and the G+C content was determined as described by Mesbah et al. (1989). Isoprenoid quinones were extracted with chloroform/methanol $(2: 1, \mathrm{v} / \mathrm{v})$, evaporated under vacuum conditions and re-extracted in n-hexane/water $(1: 1, \mathrm{v} / \mathrm{v})$. The crude $n$-hexane/quinone solution was purified using Sep-Pak Vac silica cartridges (Waters) and subsequently analysed by reversed-phase HPLC as described by Hiraishi et al. (1996). Cellular fatty acids were determined for cells prepared on NA at $30{ }^{\circ} \mathrm{C}$ for 3 days. The fatty acid methyl esters were prepared according to the protocol of the Sherlock Microbial Identification System (MIDI) and analysed by GC (model 6890; Hewlett Packard) using the Microbial Identification software (Sasser, 1990). The cellwall sugars were analysed as described by Staneck \& Roberts (1974). DNA-DNA hybridization was performed fluorometrically using the method of Ezaki et al. (1989), with photobiotin-labelled DNA probes and microdilution wells.

For analysis of the 16S rRNA gene sequence, genomic DNA was extracted using a DNA extraction kit (Solgent). PCRmediated amplification of the 16S rRNA gene and sequencing of the purified amplification products were performed according to Kim et al. (2005). Full sequences of the 16S rRNA gene were compiled using SeqMan software (DNASTAR). The 16S rRNA gene sequences of related taxa were obtained from GenBank. Multiple alignments were performed using CLUSTAL x (Thompson et al., 1997), gaps were edited using the BioEdit program (Hall, 1999) and evolutionary distances were calculated using Kimura's twoparameter model (Kimura, 1983). Phylogenetic trees were constructed with the neighbour-joining method (Saitou \& Nei, 1987) using MEGA version 3 (Kumar et al., 2004) and bootstrap values were calculated from 1000 replications (Felsenstein, 1985). The minimum-evolution and maximum-parsimony (Fitch, 1971) methods were also used to construct trees (results not shown).

Cells of strain GIMN $1.002^{\mathrm{T}}$ were Gram-reaction-positive, aerobic, weakly motile, non-spore-forming, short rods, approximately $0.4-0.6 \times 0.5-0.8 \mu \mathrm{m}$ in size after $48 \mathrm{~h}$ at $28{ }^{\circ} \mathrm{C}$ on NA. Colonies were white, nearly circular, convex with entire margins, shiny and moist. Growth occurred over a wide $\mathrm{pH}$ range $(6.0-10.0)$. The physiological and biochemical characteristics, metabolic properties and substrate-utilization results obtained for strain GIMN $1.002^{\mathrm{T}}$ are presented in Table 1 and the species description.

The cell-wall peptidoglycan contained ornithine as the diagnostic diamino acid. The major menaquinones were MK-11, MK-12 and MK-10. The acyl type of the peptidoglycan was glycolyl. The cellular fatty acids $(>1 \%$ of the total) were the branched fatty acids anteiso- $\mathrm{C}_{15: 0}$ $(38.67 \%)$, iso- $\mathrm{C}_{16: 0}(18.16 \%)$, iso- $\mathrm{C}_{15: 0}(17.46 \%)$, anteiso$\mathrm{C}_{17: 0}(7.53 \%)$ and iso- $\mathrm{C}_{14: 0}(5.16 \%)$ and the straight-chain fatty acid $\mathrm{C}_{16: 0}(2.09 \%)$. The major polar lipids detected in strain GIMN $1.002^{\mathrm{T}}$ were diphosphatidylglycerol, phosphatidylglycerol, an unidentified phospholipid and an unidentified glycolipid. The DNA G $+\mathrm{C}$ content of strain GIMN $1.002^{\mathrm{T}}$ was $67.74 \mathrm{~mol} \%$. These characteristics were well matched to the genus description of Microbacterium.

The $16 \mathrm{~S}$ rRNA gene sequence of strain GIMN $1.002^{\mathrm{T}}$ determined in this study was a continuous stretch of $1430 \mathrm{bp}$. In the neighbour-joining phylogenetic tree (Fig. 1), strain GIMN $1.002^{\mathrm{T}}$ clustered within the genus Microbacterium. Strain GIMN $1.002^{\mathrm{T}}$ exhibited the highest levels of 16S rRNA gene sequence similarity with 
Table 1. Physiological and biochemical characteristics that serve to differentiate strain GIMN $1.002^{\top}$ from its closest phylogenetic neighbours

Strains: 1, Microbacterium radiodurans sp. nov. GIMN 1.002 ${ }^{\mathrm{T}} ; 2$, M. arborescens DSM $20754^{\mathrm{T}}$ (data from Imai et al., 1984); 3, M. imperiale DSM $20530^{\mathrm{T}}$ (Collins et al., 1983); 4, M. sediminicola YM10-847 ${ }^{\mathrm{T}}$ (Kageyama et al., 2007); 5, M. ginsengisoli DSM 18659 ${ }^{\mathrm{T}}$ (Park et al., 2008); 6, M. ulmi XIL02 ${ }^{\mathrm{T}}$ (Rivas et al., 2004). +, Positive; v, variable; w, weak; -, negative; ND, no data available.

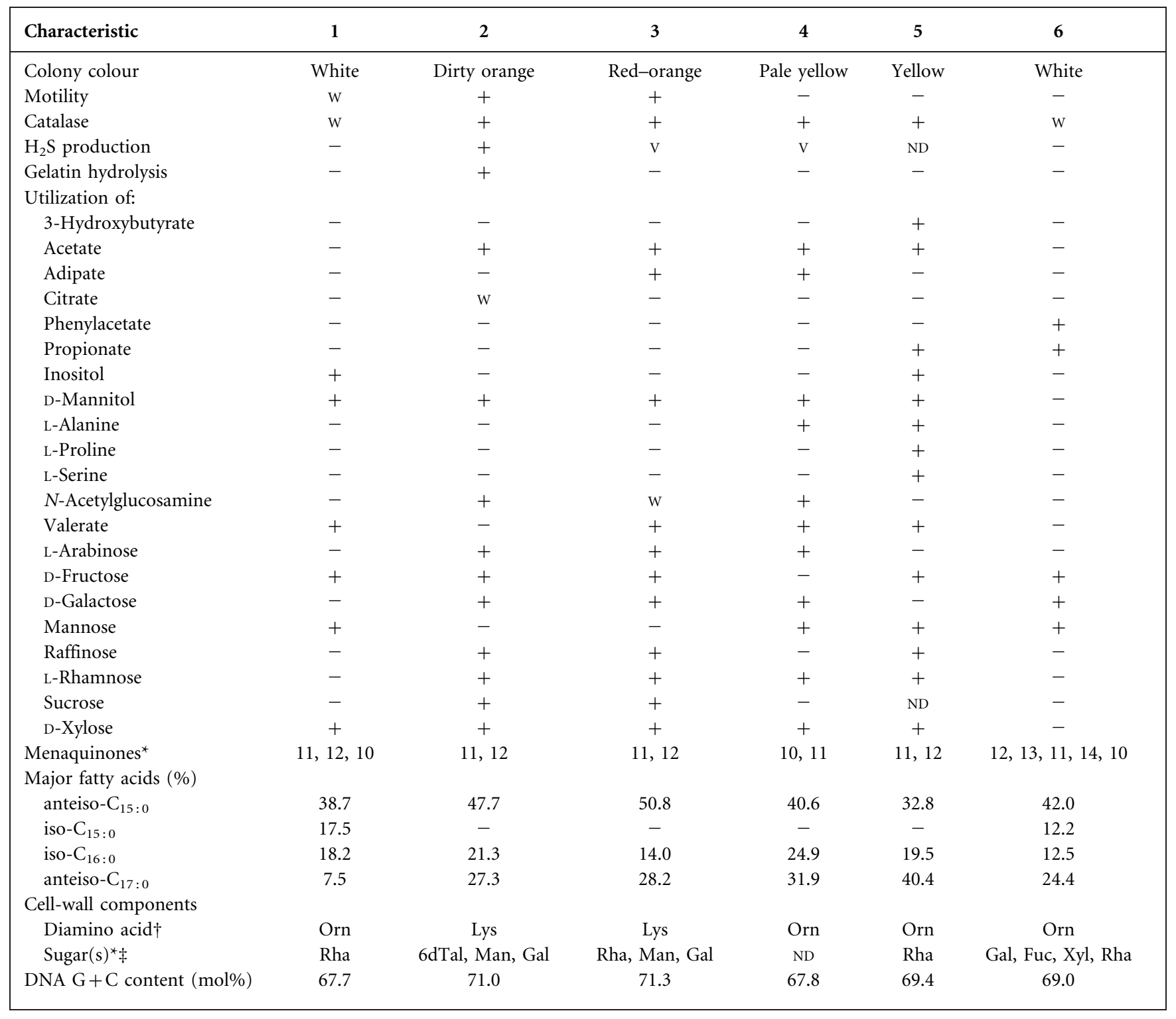

${ }^{\star}$ Components listed in decreasing order of abundance.

$\dagger$ Orn, L-Ornithine.

\$6dTal, 6-Deoxytalose; Fuc, fucose; Gal, galactose; Man, mannose; Rha, rhamnose; Xyl, xylose.

Microbacterium arborescens DSM $20754^{\mathrm{T}}(98.8 \%)$ and Microbacterium imperiale DSM $20530^{\mathrm{T}}$ (98.7\%); lower values were found with the next closest phylogenetic neighbours, Microbacterium sediminicola YM10-847 $7^{\mathrm{T}} \quad(98.3 \%)$, Microbacterium ginsengisoli Gsoil $259^{\mathrm{T}}(97.9 \%)$ and Microbacterium ulmi XIL02 ${ }^{\mathrm{T}}$ (97.8\%). Levels of DNA-DNA relatedness between strain GIMN $1.002^{\mathrm{T}}$ and M. arborescens DSM $20754^{\mathrm{T}}$ and M. imperiale DSM $20530^{\mathrm{T}}$ were $17.1 \pm 0.2$ and $12.89 \pm 0.1 \%$, respectively, which were well below the
$70 \%$ cut-off threshold for the delineation of species recommended by Wayne et al. (1987). Thus, the 16S rRNA gene sequence analysis confirmed that strain GIMN $1.002^{\mathrm{T}}$ represents a novel species of the genus Microbacterium.

The chemotaxonomic characteristics of strain GIMN $1.002^{\mathrm{T}}$ were in agreement with the results of the phylogenetic inference and confirmed that the novel bacterium belongs to the genus Microbacterium. However, strain GIMN $1.002^{\mathrm{T}}$ 


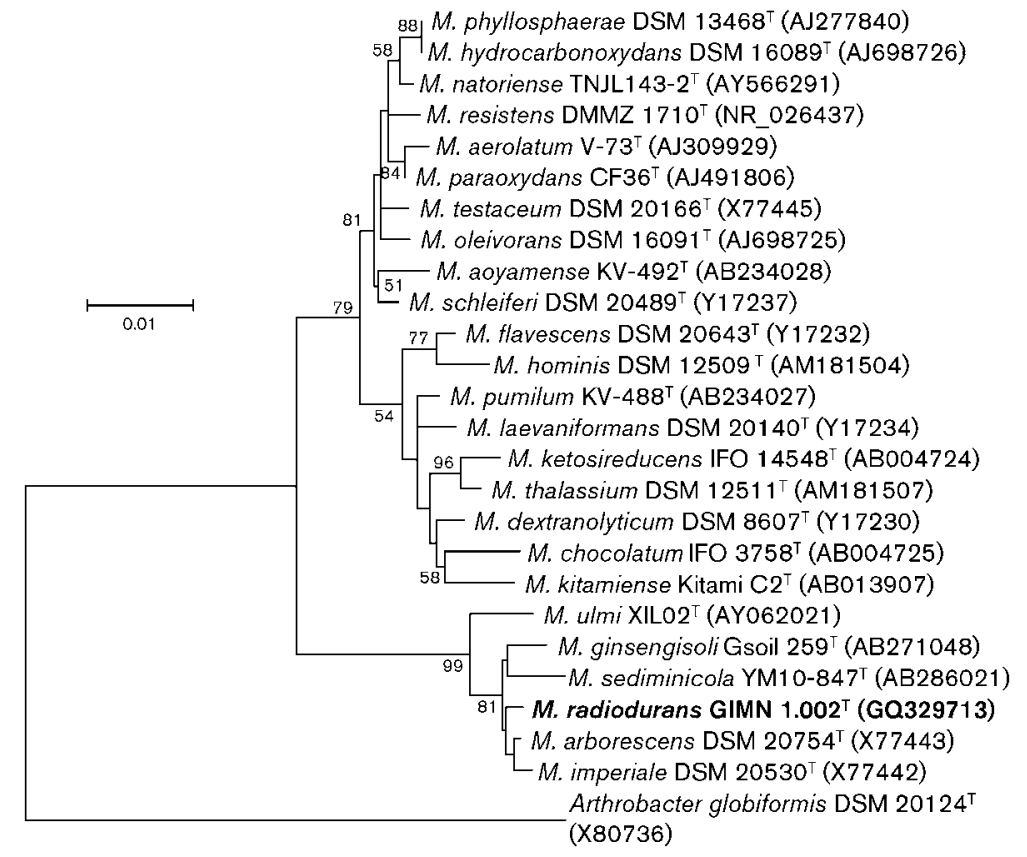

Fig. 1. Unrooted neighbour-joining tree, constructed from 16S rRNA gene sequences, showing the phylogenetic relationships between strain GIMN $1.002^{\top}$ and the type strains of other species of the genus Microbacterium. Bootstrap values (>50\%) based on 1000 replications are given at branch nodes. Arthrobacter globiformis DSM $20124^{\top}$ was used as an outgroup. Bar, 0.01 substitutions per nucleotide position. clearly differed from its closest phylogenetic neighbours (Table 1); the major fatty acids of the isolate were anteiso$\mathrm{C}_{15: 0}$, iso- $\mathrm{C}_{16: 0}$, iso- $\mathrm{C}_{15: 0}$ and anteiso- $\mathrm{C}_{17: 0}$, while those of M. arborescens and M. imperiale were anteiso- $\mathrm{C}_{15: 0}$, anteiso$\mathrm{C}_{17: 0}$ and iso- $\mathrm{C}_{16: 0}$. The cell-wall diamino acid of GIMN $1.002^{\mathrm{T}}$ was ornithine, while that of $M$. arborescens and $M$. imperiale was lysine. Only rhamnose was found in the cell wall of strain GIMN $1.002^{\mathrm{T}}$, whereas its closest phylogenetic neighbours contained several sugars.

Survival rates after exposure to doses of UV light $(254 \mathrm{~nm}$, $200 \mu \mathrm{W} \mathrm{cm}{ }^{-2}, 5 \mathrm{~min}$ ) were analysed for strain GIMN $1.002^{\mathrm{T}}$, M. arborescens DSM $20754^{\mathrm{T}}$, M. imperiale DSM $20530^{\mathrm{T}}$ and Escherichia coli K-12 CGMCC 1.3065. Cells were harvested by centrifugation at $5000 \mathrm{~g}$ and washing twice with $100 \mathrm{mM}$ potassium phosphate buffer ( $\mathrm{pH}$ 7.0). A $20-\mathrm{ml}$ cell suspension was exposed to UV radiation on a $9 \mathrm{~cm}$ plate for $5 \mathrm{~min}$. Irradiated cultures were serially diluted and $100 \mu \mathrm{l}$ aliquots were spread on tryptone/glucose/yeast agar. After incubation at $30{ }^{\circ} \mathrm{C}$ for $3-4$ days, the total c.f.u. $\mathrm{ml}^{-1}$ was determined. The survival curve of E. coli K-12 CGMCC 1.3065 dropped the most sharply, and the three Microbacterium strains demonstrated more resistance to UV light, with strain GIMN $1.002^{\mathrm{T}}$ showing the highest resistance of them all (Supplementary Fig. S1, available in IJSEM Online).

On the basis of the phenotypic, chemotaxonomic and phylogenetic data, strain GIMN $1.002^{\mathrm{T}}$ represents a novel species of the genus Microbacterium, for which the name Microbacterium radiodurans sp. nov. is proposed.

\section{Description of Microbacterium radiodurans sp. nov.}

Microbacterium radiodurans (ra.di.o.du'rans. L. n. radius a beam or ray; N.L. pref. radio- pertaining to radiation;
L. part. adj. durans enduring; N.L. part. adj. radiodurans resisting radiation).

Cells are Gram-reaction-positive, heterotrophic, strictly aerobic, weakly motile, short rods, about $0.4-0.6 \mu \mathrm{m}$ wide and $0.5-0.8 \mu \mathrm{m}$ long. Colonies grown on NA agar at $28{ }^{\circ} \mathrm{C}$ for 2 days are smooth, nearly circular, convex, transparent and white. Growth occurs at $18-30{ }^{\circ} \mathrm{C}$, at $\mathrm{pH} 6.0-10.0$ and with $<7 \%(\mathrm{w} / \mathrm{v}) \mathrm{NaCl}$. Weakly positive for catalase and negative for oxidase. Negative for aerobic and anaerobic nitrate reduction. Gelatin is not hydrolysed. With the Biolog GP2 MicroPlate system, utilizes $\beta$ cyclodextrin, cellobiose, gentiobiose, $\alpha$-D-glucose, inositol, maltose, maltotriose, D-mannitol, D-mannose, 3-methyl D-glucose, $\alpha$-ketoglutaric acid, succinic acid monomethyl ester, pyruvic acid methyl ester, glycyl L-glutamic acid, uridine, uridine $5^{\prime}$-monophosphate, D-xylose, salicin, Dsorbitol, D-fructose, putrescine, trehalose and $\alpha$-D-glucose 1 -phosphate. Does not utilize $\alpha$-cyclodextrin, dextrin, glycogen, Tween 40 or 80, L-arabinose, D-galacturonic acid, sedoheptulosan, methyl $\alpha$-D-glucoside, D-tagatose, xylitol, L-glutamic acid, lactamide, D-lactic acid methyl ester, L-alanine, L-lactic acid, D-malic acid, L-alanine, $\mathrm{N}$-acetyl-L-glutamic acid, L-serine, sucrose, raffinose, propionic acid, L-malic acid, L-rhamnose, L-alaninamide, L-pyroglutamic acid, adenosine or 2'-deoxyadenosine. The cell-wall sugar is rhamnose and the diagnostic diamino acid is ornithine. The major menaquinones are MK-11, MK-12 and MK-10. The acyl type of the peptidoglycan is glycolyl. The major polar lipids are diphosphatidylglycerol, phosphatidylglycerol, an unidentified phospholipid and an unidentified glycolipid. The fatty acids are anteiso$C_{15: 0}$, iso- $C_{16: 0}$, iso- $C_{15: 0}$, anteiso- $C_{17: 0}$, iso- $C_{14: 0}$ and $\mathrm{C}_{16: 0}$. The DNA $\mathrm{G}+\mathrm{C}$ content of the type strain is $67.74 \mathrm{~mol} \%$. 
The type strain, GIMN $1.002^{\mathrm{T}}\left(=\mathrm{CCTCC} \mathrm{M} 208212^{\mathrm{T}}\right.$ $=\mathrm{NRRL} B-24799^{\mathrm{T}}$ ), was isolated from the upper sand layers of the Gobi desert, Xinjiang, China.

\section{References}

Behrendt, U., Ulrich, A. \& Schumann, P. (2001). Description of Microbacterium foliorum sp. nov. and Microbacterium phyllosphaerae sp. nov., isolated from the phyllosphere of grasses and the surface litter after mulching the sward, and reclassification of Aureobacterium resistens (Funke et al. 1998) as Microbacterium resistens comb. nov. Int J Syst Evol Microbiol 51, 1267-1276.

Bousfield, I. J., Keddie, R. M., Dando, T. R. \& Shaw, S. (1985). Simple rapid methods of cell wall analysis as an aid in the identification of aerobic coryneform bacteria. In Chemical Methods in Bacterial Systematics, pp. 221-236. Edited by M. Goodfellow \& D. E. Minnikin. London: Academic Press.

Buck, J. D. (1982). Nonstaining ( $\mathrm{KOH})$ method for determination of Gram reactions of marine bacteria. Appl Environ Microbiol 44, 992 993.

Collins, M. D., Jones, D. \& Kroppenstedt, R. M. (1983). Reclassification of Brevibacterium imperiale (Steinhaus) and 'Corynebacterium laevaniformans' (Dias and Bhat) in a redefined genus Microbacterium (Orla-Jensen), as Microbacterium imperiale comb. nov. and Microbacterium laevaniformans nom. rev.; comb. nov. Syst Appl Microbiol 4, 65-78.

Ezaki, T., Hashimoto, Y. \& Yabuuchi, E. (1989). Fluorometric deoxyribonucleic acid-deoxyribonucleic acid hybridization in microdilution wells as an alternative to membrane filter hybridization in which radioisotopes are used to determine genetic relatedness among bacterial strains. Int J Syst Bacteriol 39, 224229.

Felsenstein, J. (1985). Confidence limits on phylogenies: an approach using the bootstrap. Evolution 39, 783-791.

Fitch, W. M. (1971). Toward defining the course of evolution: minimum change for a specific tree topology. Syst Zool 20, 406416.

Hall, T. A. (1999). BioEdit: a user-friendly biological sequence alignment editor and analysis program for Windows 95/98/NT. Nucleic Acids Symp Ser 41, 95-98.

Hiraishi, A., Ueda, Y., Ishihara, J. \& Mori, T. (1996). Comparative lipoquinone analysis of influent sewage and activated sludge by highperformance liquid chromatography and photodiode array detection. J Gen Appl Microbiol 42, 457-469.

Imai, K., Takeuchi, M. \& Banno, I. (1984). Reclassification of 'Flavobacterium arborescens' (Frankland and Frankland) Bergey et al. in the genus Microbacterium (Orla-Jensen) Collins et al., as Microbacterium arborescens comb. nov., nom. rev. Curr Microbiol 11, 281-284.

Kageyama, A., Takahashi, Y., Matsuo, Y., Kasai, H., Shizuri, Y. \& Omura, S. (2007). Microbacterium sediminicola sp. nov. and Microbacterium marinilacus sp. nov., isolated from marine environments. Int J Syst Bacteriol 57, 2355-2359.

Kim, M. K., Im, W.-T., Ohta, H., Lee, M. \& Lee, S.-T. (2005). Sphingopyxis granuli sp. nov., a beta-glucosidase-producing bacterium in the family Sphingomonadaceae in alpha-4 subclass of the Proteobacteria. J Microbiol 43, 152-157.

Kimura, M. (1983). The Neutral Theory of Molecular Evolution. Cambridge: Cambridge University Press.

Komagata, K. \& Suzuki, K. (1987). Lipid and cell-wall analysis in bacterial systematics. Methods Microbiol 19, 161-207.
Kumar, S., Tamura, K. \& Nei, M. (2004). MEGA3: integrated software for molecular evolutionary genetics analysis and sequence alignment. Brief Bioinform 5, 150-163.

Mesbah, M., Premachandran, U. \& Whitman, W. B. (1989). Precise measurement of the $\mathrm{G}+\mathrm{C}$ content of deoxyribonucleic acid by highperformance liquid chromatography. Int J Syst Bacteriol 39, 159-167.

Minnikin, D. E., O'Donnell, A. G., Goodfellow, M., Alderson, G., Athalye, M., Schaal, A. \& Parlett, J. H. (1984). An integrated procedure for the extraction of bacterial isoprenoid quinones and polar lipids. J Microbiol Methods 2, 233-241.

Moore, D. D. \& Dowhan, D. (1995). Preparation and analysis of DNA. In Current Protocols in Molecular Biology, pp. 2-11. Edited by F. W. Ausubel, R. Brent, R. E. Kingston, D. D. Moore, J. G. Seidman, J. A. Smith \& K. Struhl. New York: Wiley.

Orla-Jensen, S. (1919). The Lactic Acid Bacteria. Copenhagen: Høst \& Sons.

Park, M. J., Kim, M. K., Kim, H. B., Im, W. T., Yi, T. H., Kim, S. Y., Soung, N. K. \& Yang, D. C. (2008). Microbacterium ginsengisoli sp. nov., a $\beta$-glucosidase-producing bacterium isolated from soil of a ginseng field. Int J Syst Evol Microbiol 58, 429-433.

Rivas, R., Trujillo, M. E., Sánchez, M., Mateos, P. F., Martínez-Molina, E. \& Velázquez, E. (2004). Microbacterium ulmi sp. nov., a xylanolytic, phosphate-solubilizing bacterium isolated from sawdust of Ulmus nigra. Int J Syst Evol Microbiol 54, 513-517.

Saitou, N. \& Nei, M. (1987). The neighbor-joining method: a new method for reconstructing phylogenetic trees. Mol Biol Evol 4, 406425.

Sasser, M. (1990). Identification of bacteria by gas chromatography of cellular fatty acids, MIDI Technical Note 101. Newark, DE: MIDI, Inc.

Schumann, P., Rainey, F. A., Burghardt, J., Stackebrandt, E. \& Weiss, N. (1999). Reclassification of Brevibacterium oxydans (Chatelain and Second 1966) as Microbacterium oxydans comb. nov. Int J Syst Bacteriol 49, 175177.

Skerman, V. B. D. (1967). A Guide to the Identification of the Genera of Bacteria, 2nd edn. Baltimore: Williams \& Wilkins.

Smibert, R. M. \& Krieg, N. R. (1981). General characterization. In Manual of Methods for General Bacteriology, p. 409-425. Edited by P. Gerhardt, R. G. E. Murray, R. N. Costilow, E. W. Nester, W. A. Wood, N. R. Krieg \& G. B. Phillips. Washington, DC: American Society for Microbiology.

Sneath, P. H. A., Mair, N. S., Sharpe, M. E. \& Holt, J. G. (editors) (1986). Bergey's Manual of Systematic Bacteriology, vol. 2. Baltimore: Williams \& Wilkins.

Staneck, J. L. \& Roberts, G. D. (1974). Simplified approach to identification of aerobic actinomycetes by thin-layer chromatography. Appl Microbiol 28, 226-231.

Takeuchi, M. \& Hatano, K. (1998a). Proposal of six new species in the genus Microbacterium and transfer of Flavobacterium marinotypicum ZoBell and Upham to the genus Microbacterium as Microbacterium maritypicum comb. nov. Int J Syst Bacteriol 48, 973-982.

Takeuchi, M. \& Hatano, K. (1998b). Union of the genera Microbacterium Orla-Jensen and Aureobacterium Collins et al. in a redefined genus Microbacterium. Int J Syst Bacteriol 48, 739-747.

Thompson, J. D., Gibson, T. J., Plewniak, F., Jeanmougin, F. \& Higgins, D. G. (1997). The CLUSTAL_X windows interface: flexible strategies for multiple sequence alignment aided by quality analysis tools. Nucleic Acids Res 25, 4876-4882.

Uchida, K. \& Seino, A. (1997). Intra- and intergeneric relationships of various actinomycete strains based on the acyl types of the muramyl residue in cell wall peptidoglycans examined in a glycolate test. Int $J$ Syst Bacteriol 47, 182-190. 
Wayne, L. G., Brenner, D. J., Colwell, R. R., Grimont, P. A. D., Kandler, O., Krichevsky, M. I., Moore, L. H., Moore, W. E. C., Murray, R. G. E. \& other authors (1987). International Committee on Systematic
Bacteriology. Report of the ad hoc committee on reconciliation of approaches to bacterial systematics. Int J Syst Bacteriol 37, 463-464. 